\title{
Sildenafil Citrate in Management of Intrauterine Growth Restriction: A Case Study
}

\author{
Syed Umer Farooq ${ }^{1}$, Rifat Ara ${ }^{2}$, Suhail Ahmad Mir ${ }^{1}$, Ozaifa Kareem ${ }^{1}$, Rumaisa Rashid ${ }^{1}$ and G N Bader ${ }^{1 *}$ \\ ${ }^{1}$ Department of Pharmaceutical Sciences, University of Kashmir, India \\ ${ }^{2}$ Department of Obstetrics \& Gynecology, Sher-i-Kashmir Institute of Medical Sciences, India
}

Submission: May 13, 2019 ; Published: May 22, 2019

*Corresponding author: Ghulam N Bader, Department of Pharmaceutical Sciences, University of Kashmir, India

\begin{abstract}
Background: In IUGR the fetus fails to achieve its normal growth potential. For achieving optimal fetal growth, an adequate blood flow in uteroplacental vascular bed is essential. Abnormal vasculature adaptations that result in aberrant blood flow have been implicated as a possible cause of IUGR. Sildenafil is a PDE-5 inhibitor. Because of its vasodilator action, it might offer an alternative in the treatment of IUGR by improvement in Doppler velocimetric indices.
\end{abstract}

Case presentation: In this study a case of pregnancy complicated with IUGR was examined and sildenafil was orally administered to her.

Conclusion: Sildenafil citrate being a vasodilator offers a novel and excellent option in the management of pregnancies complicated with IUGR by improving fetoplacental circulation as evident by improved umbilical artery Doppler indices and improved fetal weight.

Keywords: IUGR; Umbilical Artery Doppler; Sildenafil Citrate

Abbreviatations: IUGR: Intrauterine Growth Restriction; ACOG: American College of Obstetrics and Gynecology; RCOG: Royal College of Obstetrics And Gynecology; SKIMS: Sher-I-Kashmir Institute Of Medical Sciences; RI: Resistive Index; PI: Pulsatility Index; ALP: Alkaline Phosphatase; LFT: Liver Function Test

\section{Introduction}

Intrauterine growth restriction (IUGR) is defined as a fetus at or below the 10 th percentile in weight for its gestational age as adopted by the American College of Obstetrics and Gynecology (ACOG) and the Royal College of Obstetrics and Gynecology (RCOG). Early-onset IUGR is often associated with high perinatal morbidity and mortality [1]. As placental size, uteroplacental blood flow, and expression of angiogenic and vasoactive factors are altered in pregnancies complicated by IUGR, it has been suggested that therapeutic agents that target placental blood flow might be used in management of such pregnancies [2]. Currently, there is no standard pharmaco-therapy for the management of IUGR, however, few studies conducted so far have suggested the effectiveness of sildenafil in this pregnancy related complication. Sildenafil is a selective PDE-5 inhibitor. It increases uterine blood flow by its vasodilatory action. In this case-study, sildenafil citrate therapy was able to decrease umbilical artery Doppler indices and resulted in favorable neonatal outcome.

\section{Case Presentation}

A 29-year-old G3A2 hypothyroid 18week pregnant female attended the OPD of Obstetrics and Gynecology Department,
Sher-I-Kashmir Institute of Medical Sciences (SKIMS), Medical College and Hospital, for antenatal check up in the month of May 2018. First trimester of pregnancy was normal in course. Patient was asked for a biweekly antenatal follow up. At 20 weeks ultrasonography was performed which was normal without any evidence of fetal anomaly. Repeat USG along with color Doppler was performed at 26 weeks which showed fetal weight of 620 grams. Color Doppler showed raised umbilical artery systolic/ diastolic (s/d) ratio of 4.3, resistive index (RI) 0.80 and pulsatility index (PI) 1.88. The Doppler and USG findings were suggestive of placental insufficiency and IUGR. Patient was advised bed rest and sildenafil citrate at $20 \mathrm{mg}$ twice a day was prescribed to her. Moreover, the liver function test (LFT) of patient showed raised alkaline phosphatase (ALP), aspartate aminotransferase (AST) and alanine aminotransferase (ALT) levels, for which ursodeoxycholic acid $150 \mathrm{mg}$ twice a day was prescribed. The patient and her husband were counselled regarding risks and bleak prognosis of the pregnancy.

USG and Doppler were performed weekly to access the fetal parameters. After 4 weeks of starting sildenafil therapy, i.e. at 30 weeks, Doppler showed improved umbilical artery diastolic flow, 
s/d ratio of 3.6 RI: 0.74 and PI: 1.71 . The fetal weight at 30 weeks was around 1100 grams. After 30 weeks the dose sildenafil was increased to $20 \mathrm{mg}$ thrice a day. Repeat USG and Doppler were performed at 32 weeks, which showed further improvement with umbilical artery s/d ratio of 3.1, RI 0.66 and PI: 1.51. The fetal weight at 32 weeks was around 1450 grams.

The treatment with sildenafil was continued up to 34 th week. Doppler performed at 34th week showed further gradual improvement in uteroplacental perfusion with $\mathrm{s} / \mathrm{d}$ ratio of 2.9, RI: 0.64 and PI: 1.21 . Cesarean was performed at 35 th week and normal male child of $2.1 \mathrm{~kg}$ was delivered. The maternal and neonatal courses were uneventful. The infant was examined by pediatrician and found to be normal.

\section{Discussion}

Fetal growth restriction results from the factors which alter uteroplacental perfusion and therefore alter the nutrient delivery to the fetus $[3,4]$. IUGR has a multifactorial etiology and it is hard to define a specific cause. The onset of IUGR is due to the factors of maternal, fetal and placental origin and an increase in oxidative stress [5]. Maternal factors such as severe maternal malnutrition, underweight at the beginning of gestation and low weight gain during the gestation are the causative factors of IUGR [6]. Chronic maternal stress compromises normal regulation of hormonal activity during gestation, because it increases $\beta$-endorphin, glucocorticoids, catecholamines and CRH (corticotrophin-releasing hormone) levels. An excess of the aforementioned hormones, in addition to an increase in cortisol levels, breaks through the placenta and can reduce fetal weight at birth. Catecholamines can also induce vasoconstriction of blood vessels causing placental hypoxia in the fetus $[7,8]$. In animal models it has been observed that hypoxia induces a decrease of serum vitamin E levels and an increase in thromboxane production [9]. These metabolic alterations are responsible for an abnormal placental development and the decrease in steroid production. All these changes could lead to a feto-placental vascular resistance and an increase of oxidative stress, which could be responsible for the appearance of IUGR $[10,11]$.

The placenta, as a key organ for fetal growth, has a major role in amino acid transport, the most important nutrient for fetal life. During pregnancy, there is an active transport across the placenta from the maternal to the fetal circulation. In IUGR pregnancies, the concentrations of most essential amino acids (valine, leucine and isoleucine) are decreased in fetal tissues but are significantly higher in maternal tissues leading to pregnancy maladaptation [12]. Several studies in animals have shown a significantly reduced uptake of oxygen, glucose and essential amino acids in IUGR pregnancies [13-15]. Also, in vitro study in humans has shown a reduced uptake of leucine and lysine, suggesting a reduced activity of cationic amino acid transporters [12]. Together, this data suggests that the amino acid transport has a key role to play in the fetal development. The deficiency of these amino acid transporters results in IUGR pregnancies [16]. Sildenafil Citrate is a selective PDE-5 inhibitor. It acts by preventing the degradation of the second messenger cyclic guanosine $3^{\prime}, 5^{\prime}$-monophosphate by the enzyme PDE-5. This results in increased nitric oxide production and consequent vascular smooth muscle relaxation and an increase in vasodilation [17]. It increases uterine blood flow by improving endothelial function of myometrial vessels [18]. Additionally, sildenafil potentiates estrogen induced vasodilation [19]. Various studies have shown that sildenafil improves uteroplacental blood flow which in turn improves fetal weight by increased availability of oxygen and nutrients to fetus $[20,21]$. In this case study administration of sildenafil improved the umbilical artery indices and fetal weight. A normal baby was delivered with uneventful neonatal follow up.

\section{References}

1. Bichat AA (2004) Doppler application in the delivery timing of the preterm growth-restricted fetus: another step in the right direction. Ultrasound Obstet Gynecol 23(2): 111-118.

2. Wareing M, Myers JE, O'Hara M, Baker PN (2005) Sildenafil citrate (Viagra) enhances vasodilatation in fetal growth restriction. J Clin Endocrinol Metab 90(5): 2550-2555.

3. Lee MJ, Conner EL, Charafeddine L, Woods JR, Del Priore G (2001) A critical birth weight and other determinants of survival for infants with severe intrauterine growth restriction. Ann N Y Acad Sci 943: 326-339.

4. Lam C, Lim KH, Karumanchi SA (2005) Circulating angiogenic factors in the pathogenesis and prediction of preeclampsia. Hypertension 46(5): 1077-1085.

5. Bamfo JE, Odibo AO (2011) Diagnosis and management of fetal growth restriction. J Pregnancy, 640715.

6. Mitchell EA, Robinson E, Clark PM, Becroft DMO, Glavish N, et al. (2004) Maternal nutritional risk factors for small for gestational age babies in a developed country: a case-control study. Arch Dis Child Fetal Neonatal Ed 89(5): F431-F435.

7. Valsamakis G, Kanaka-Gantenbein C, Malamitsi-Puchner A, Mastorakos G (2006) Causes of intrauterine growth restriction and the postnatal development of the metabolic syndrome. Ann NY Acad Sci 1092: 138147.

8. Weinstock M (2005) The potential influence of maternal stress hormones on development and mental health of the offspring. Brain Behav Immun 19(4): 296-308.

9. Sorem KA, Siler-Khodr TM (1997) Effect of IGF-I on placental thromboxane and prostacyclin release in severe intrauterine growth retardation. J Matern Fetal Med 6(6): 341-350.

10. Parraguez VH, Urquieta B, Reyes DLM, Gonzalez-Bulnes A, Astiz S, et al. (2013) Steroidogenesis in sheep pregnancy with intrauterine growth retardation by high-altitude hypoxia: effects of maternal altitudinal status and antioxidant treatment. Reprod Fertil 25(4): 639-645.

11. Majed BH, Khalil RA (2012) Molecular mechanisms regulating the vascular prostacyclin pathways and their adaptation during pregnancy and in the newborn. Pharmacol Rev 64(3): 540-582.

12. Jansson T, Scholtbach V, Powell TL (1998) Placental transport of leucine and lysine is reduced in intrauterine growth restriction. Pediatr Res 44(4): 532-537.

13. Anderson MS, Thamotharan M, Kao D, Devaskar SU, Qiao L, et al. (2005) Effects of acute hyperinsulinemia on insulin signal transduction and 
glucose transporters in ovine fetal skeletal muscle. Am J Physiol Regul Integr Comp Physiol 288(2): R473-R481.

14. Philipps AF, Rosenkrantz TS, Lemons JA, Knox I, Porte PJ, et al. (1990) Insulin-induced alterations in amino acid metabolism in the fetal lamb. J Dev Biol 13(5): 251-259.

15. Regnault TRH, Vrijer DB, Battaglia FC, Meschia G, Wilkening RB, et al. (2004) Relationship of transplacental oxygen gradient, fetal lactate concentration and amino acid uptake in fetal growth restriction Journal of the Society for Gynecologic Investigation 11(2): A823.

16. Avagliano L, Garo C, Marconi AM (2012) Placental amino acids transport in intrauterine growth restriction. J Pregnancy.

17. Mehrotra N, Gupta M, Kovar A (2007) The role of pharmacokinetics and pharmacodynamics in phosphodiesterase 5 inhibitor therapy. Int J Impot Res 19(3): 253-264.
18. Jennifer MS, Chris B (2010) Effects of sildenafil on maternal hemodynamics and fetal growth in normal rat pregnancy. Am J Physiol Regul Integr Comp Physiol 298(2): R433-R438.

19. Zoma WD, Baker RS, Clark KE (2004) Effects of combined use of sildenafil citrate (Viagra) and 17 beta-estradiol on ovine coronary and uterine hemodynamics. Am J Obstet Gynecol 190(5): 1291-1297.

20. Singh A, Daharwal A, Kujur A, Awasthi P (2017) Effect of sildenafil on IUGR. International Journal of Reproduction, Contraception, Obstetrics and Gynecology 6(5): 1807.

21. Anwar MH, Hasanin MK, Abdelaziz BR, Hamd OA (2018) Effect of Sildenafil Citrate on Fetal Color Doppler Study and Biophysical Profile in Cases of Intrauterine Growth Restriction (IUGR) in Third Trimester. The Egyptian Journal of Hospital Medicine 72(11): 5571-5574.

\section{Your next submission with Juniper Publishers will reach you the below assets}

- Quality Editorial service

- Swift Peer Review

- Reprints availability

- E-prints Service

- Manuscript Podcast for convenient understanding

- Global attainment for your research

- Manuscript accessibility in different formats

( Pdf, E-pub, Full Text, Audio)

- Unceasing customer service

Track the below URL for one-step submission https://juniperpublishers.com/online-submission.php 